INTUISI 12 (1) (2020)
INTUISI
JURNAL PSIKOLOGI ILMIAH
$\begin{gathered}\text { http://journal.unnes.ac.id/nju/index.php/INTUISI } \\ \text { Terindeks DOAJ: 2541-2965 }\end{gathered}$

\title{
"BAGAIMANA MEREKA MENGUBAHKU?" (INTERPRETATIVE PHENOMENOLOGICAL ANALYSIS TENTANG REKONSTRUKSI IDENTITAS PADA MUSLIMAH BERCADAR)
}

\author{
Santi Riksa Pratiwi ${ }^{1 \bowtie}$, Nuke Martiarini ${ }^{2}$ \\ ${ }^{1}$ Rumah Duta Revolusi Mental \\ ${ }^{2}$ Jurusan Psikologi, Fakultas Ilmu Pendidikan Universitas Negeri Semarang, Indonesia
}

\begin{tabular}{l}
\hline Info Artikel \\
\hline Sejarah Artikel: \\
Disubmit 28 Februari 2020 \\
Direvisi 18 April 2020 \\
Diterima 26 April 2020
\end{tabular}

\section{Keywords:}

Identity Reconstruction, Veiled Muslim Woman, Community

\begin{abstract}
Abstrak
Persepsi masyarakat terhadap muslimah bercadar cederung negatif, namun masih terdapat individu yang memilih untuk bercadar. Diperlukan pemahaman lebih lanjut terkait pembentukan identitas baru atau rekonstruksi identitas pada muslimah bercadar. Tujuan dari penelitian ini untuk mengetahui bagaimana konstruksi identitas yang terbentuk berkaitan dengan identitas diri dan identitas sosial pada muslimah bercadar. Jenis penelitian yang digunakan adalah penelitian kualitatif dengan menggunakan pendekatan fenomenologis. Sumber data dari penelitian ini adalah muslimah yang telah menggunakan cadar minimal dalam waktu 6 bulan dan menjadi bagian dari komunitas $\mathrm{P} * * * * * *$. Teknik pengumpulan data yang digunakan yaitu dengan menggunakan wawancara. Sebagai wujud dari kredibilitas penelitian, peneliti menggunakan kualitas penelitian dengan merujuk pada empat kualitas esensial. Teknik analisis data yang digunakan oleh peneliti merupakan teknik analisis data melalui pendekatan fenomenologis dengan IPA (Interpretatif phenomenological analysis). Hasil penelitian menemukan sepuluh tema berkaitan dengan fungsi kognitif, perasaan, perilaku, dan faktor yang mempengaruhinya. Fungsi kognitif yang muncul pada muslimah bercadar yaitu pemikiran bahwa cadar sangat bermanfaat, ketaatan terhadap hukum agama semakin kuat, keinginan berbuat baik agar mendapatkan surga, pengalaman buruk dengan laki-laki hingga mengenal cadar, serta meneladani kepribadian Rasul dan sahabat Rasul. Tema terkait perasaan yaitu perasaan lebih nyaman ketika bercadar. Tema terkait perilaku yaitu berperilaku sebaik mungkin dan mengajak orang lain. Tema terkait faktor yang mempengaruhi muslimah bercadar yaitu keluarga yang memahami keputusan untuk bercadar, pengaruh komunitas dakwah $\mathrm{P} * * * * * *$ yang cukup kuat, serta lingkungan pertemanan, tetangga dan masyarakat umum yang kurang mendukung.

Abstract

Public perceptions of veiled Muslim women tend to be negative, but there are person who still choose to veiled. Further understanding is necessary regarding the construction of a new identity or identity reconstruction in veiled Muslim women. The aim of the study was to find out how identity construction formed was related to self identity and social identity in veiled Muslim women. The type of this study was qualitative research using a phenomenological approach. Sources of data from this study are Muslim women who have used veils in the span of 6 months to 2 years and become part of the $P * * * * * *$ community. Data were collected by interviews. As a research credibility, researcher use the quality of research by referring to four essensial qualities. The data analysis technique used by researchers is a data analysis technique through a phenomenological approach with IPA (Interpretative phenomenological analysis). The results of the study, found ten themes about cognitive functions, feelings, behaviors, and factors that influence it. Themes about cognitive namely the thought that the veil is very useful, adherence to religious law is getting stronger, the desire to do good to get heaven, bad experiences with men untill she wore the veil, emulate personality of Apostle and friend of the Apostle. There are a theme about feeling, that was feeling more comfortable when using veil. Themes about behaviors, that was behaving as well as possible and inviting others, families who understanding the decision to veiled, the influence of the $P * * * * * * d a$ 'wah community is strong enough, and the environment of friends, neighbors and the general public is less supportive. These themes were concluded to lead to identity reconstruction in veiled Muslim women.
\end{abstract}

(C) 2020 Universitas Negeri Semarang 


\section{PENDAHULUAN}

Pakaian atau busana merupakan salah satu bagian yang tak terpisahkan dari kehidupan sehari-hari, baik bagi laki-laki maupun perempuan. Perilaku pemilihan cara berpakaian merupakan salah satu cara untuk membantu pembentukan identitas pada diri individu. Identitas berfungsi dalam pengidentifikasian sebuah penghayatan mengenai diri secara personal maupun sosial. Muttaqin dan Ekowarni (2016) menyatakan bahwa remaja perempuan dapat lebih mengoptimalkan kesempatan dalam pembentukan identitas dibandingkan dengan lelaki, sehingga remaja perempuan memiliki lebih banyak variasi dalam berpakaian.

Secara umum fungsi pakaian adalah untuk menutupi bagian-bagian tubuh tertentu, namun bagi perempuan pakaian memiliki fungsi lain yaitu sebagai aksesoris. Penelitian yang dilakukan oleh Kang, Johnson, \& Kim (2013) menunjukkan bahwa perempuan memilih sebuah pakaian karena berbagai fungsi dalam waktu yang bersamaan (misalkan kenyamanan dan fashionability) daripada memilih pakaian berdasarkan satu fungsi tertentu (fungsi utama).

Terlepas dari fungsi utama berpakaian, kini pakaian mulai dijadikan bahan komersial, dalam hal ini pakaian menjadi peluang bagi beberapa individu untuk mendapatkan keuntungan secara material melalui proses perdagangan. Hal tersebut tidak terlepas dari peran modernisasi yang menciptakan berbagai macam trend masa kini, mulai dari munculnya berbagai macam jenis serta model pakaian hingga perpaduan berbagai warna yang menarik perhatian. Berdasarkan penelitian Yazid dan Ridwan (2017), interpretasi mahasiswi terhadap pemilihan dan pengorganisasian berbusana muslimah dipengaruhi oleh trend yang sedang digemari saat ini.

Trend yang mempengaruhi cara berbusana seseorang khususnya pada muslimah secara tidak langsung akan membentuk dua kelompok besar, yaitu kelompok yang mengikuti trend serta kelompok yang tidak mengikuti trend. Kelompok yang memilih untuk tidak mengikuti trend memiliki alasan tersendiri, salah satunya adalah untuk mengikuti ketentuan agama yang dianut. Mulai dari pemilihan pakaian yang panjang dan tidak memperlihatkan lekuk tubuh hingga pemilihan warna pakaian gelap dan tidak menarik banyak perhatian, namun tidak semua kelompok yang mengikuti trend tidak mengikuti ketentuan agama, karena masih ada anggota kelompok yang mengikuti trend namun masih sesuai dengan ketentuan agama yang dianut. Berdasarkan hasil penelitian Rinawati (2007), gaya hidup "gaul" menjadi "trend" remaja Muslimah saat ini. Hal ini sebagai cerminan adanya kolaborasi antara tuntutan ajaran agama dengan budaya pop.

Muslimah yang bercadar memiliki kecenderungan tidak mengikuti trend yang ada, mereka lebih memilih memakai pakaian dengan warna yang senada dan tidak mencolok seperti warna hitam, biru tua, dan warna-warna gelap lainnya, namun masih terdapat beberapa muslimah bercadar yang mengikuti trend dengan munculnya berbagai warna-warna cadar yang cerah seperti warna merah muda, biru muda dan warna-warna lainnya. Muslimah bercadar yang mengikuti trend tidak melepaskan ajaran yang dianutnya. Mereka tetap berusaha menutup aurat dengan menggunakan pakaian yang longgar serta panjang sehingga dapat menutup bagian-bagian tubuhnya dengan sempurna. Berdasarkan hasil penelitian Nisa dan Rudianto (2017), jilbab tidak hanya wajib bagi wanita muslim tetapi juga merupakan trend yang dimiliki oleh para wanita muslim dan mampu memberikan gambaran kepada masyarakat tentang konsep wanita muslim sesuai dengan ajaran dan prinsip Islam.

Penelitian yang dilakukan oleh Amanda dan Mardianto (2014), ditemukan fakta bahwa prasangka masyarakat masih 
negatif yang memiliki indikasi kedekatan yang kurang intim dengan muslimah yang bercadar. Hal tersebut berdampak pada besarnya pada jarak sosial antara masyarakat dengan muslimah yang bercadar, sedangkan untuk menciptakan kondisi mental yang sehat diperlukan suasana masyarakat yang kondusif dan positif dimana setiap individu mampu menghargai perbedaan yang ada. Khususnya untuk negara Indonesia yang memiliki keberagaman yang sangat kompleks.

Cara berpakaian merupakan salah satu perwujudan dari identitas seseorang, seperti penelitian yang dilakukan oleh Feinberg, Mataro, \& Burroughs (2015) yaitu ada hubungan erat antara makna dari pakaian yang digunakan dengan identitas sosial pada diri individu. Ketika seorang perempuan memiliki identitas sosial sebagai pemeluk agama islam maka akan memilih untuk menggunakan pakaian yang sesuai atau mendekati syariat Islam. Busana atau pakaian yang sesuai dengan syariat Islam merupakan perwujudan dari konsep berbusana dengan cara menutup aurat.

Menurut Barker (2004) konstruksi identitas terbagi dalam dua bentuk, yaitu identitas sosial serta identitas pribadi. Identitas sosial dipengaruhi oleh perubahan sosial. Perubahan sosial diakibatkan oleh teknologi yang mengarah pada indutri dan kapital serta perubahan ideologi dan gender. Dimana perubahan sosial dapat berakibat pada perilaku manusia, salah satunya adalah perubahan gaya hidup (Soeparno \& Andayani, 2014). Identitas sosial tidak terlepas dari konsep in-group dan out-group. Hal tersebut berkaitan dengan perasaan persamaan dan perbedaan antara satu kelompok dengan kelompok lainnya. Persamaan dengan beberapa orang akan menjadikan mereka pada posisi in-group, sedangkan perbedaan menjadikan mereka pada posisi out-group.

Identitas menurut Barker (2004) terdiri atas dua bentuk yaitu identitas diri dan identitas sosial atau social identity. Adapun penjelasan tentang bentuk-bentuk identitas tersebut menurut Giddens (Barker, 2004) adalah sebagai berikut; a) Identitas diri. Identitas diri dianggap sebagai sebuah proyek dimana individu berusaha mengkonstruksi suatu narasi identitas yang koheren yang 'membentuk suatu lintasan perkembangan dari masa lalu sampai masa depan yang dapat diperkirakan.

Identitas diri terdiri atas berbagai aspek, menurut Yusuf (2004) aspek-aspek identitas diri adalah fisik, kemampuan intelektual, emosi, sikap dan nilai-nilai (kepercayaan apa saja yang diyakini oleh individu dalam menjalani hidupnya), b) Identitas Sosial. Menurut Giddens (dalam Barker, 2004) identitas sosial diasosiasikan dengan hak-hak normatif, kewajiban, dan sanksi, yang pada kolektivitas tertentu membentuk sebuah peran. Pemakaian atributatribut seperti umur dan gender merupakan hal fundamental di masyarakat. Identitas sosial terdiri atas berbagai aspek, menurut Baron dan Byrne (2003) aspek-aspek identitas sosial adalah the self dan gender.

Menurut Santrock (2007) faktorfaktor yang mempengaruhi pembentukan identitas adalah sebagai berikut: a) Pengaruh keluarga terhadap identitas. Pembentukan identitas ditingkatkan melalui relasi keluarga, selain itu kondisi budaya yang bervariasi juga berpengaruh (Cooper dalam Santrock, 2007), b) Identitas budaya dan etnis. Menurut Bryant, et.al. (Santrock, 2007) identitas individu yang berasal dari kelompok minoritas dalam proses pembentukan identitas memiliki dua dimensi, yaitu: pilihan diantara dua atau lebih sumber identifikasi (kelompok etnisnya dan budaya yang dominan). Identitas etnis dianggap lebih kuat diantara anggota kelompok minoritas dengan kelompok mayoritas, c) Gender. Menurut Erikson (Santrock, 2007) laki-laki lebih berorientasi pada karier dan komitmen ideologi, sementara 
perempuan lebih berorientasi pada perkawinan dan pengasuhan anak.

Berkaitan dengan cadar, terdapat beberapa pendapat dari ulama (Yanggo, 2010) terkait hukum menutup menutup aurat perempuan, yaitu : 1) Pendapat dari mayoritas mazhab, antara lain : Imam Malik, Ibn Syafi'i dan Imam Ahmad dalam riwayat yang masyhur dari keduanya, Hanafiyah dan Syi'ah Imamiyah dalam satu riwayat, para sahabat Nabi dan Tabi'in (Ali, Ibn Abbas, Aisyah, 'Atha, Mujahid, Al-Hasan, dll) menyatakan bahwa aurat bagi perempuan Muslim adalah seluruh tubuh kecuali wajah dan kedua telapak tangan, 2) Pendapat AtsTsauri da Al-Muzani, Al-Hanifah, dan Syi'ah Imamiah menurut riwayat yang shahih menyatakan bahwa aurat dari perempuan Muslim adalah seluruh tubuh kecuali wajah, kedua telapak tangan dan kedua telapak kaki, 3) Pendapat dari Imam Ahmad dalam salah satu riwayat, serta pendapat Abu Bakar dan Abd Rahman dari kalangan Tabi'in menyatakan bahwa seluruh tubuh dari perempuan Muslim adalah aurat, 4) Pendapat Imam Ahmad dalam satu riwayat dan pendapat Daud Al-Zhahiri serta sebagian Syi'ah Zaidah menyatakan bahwa aurat dari perempuan Muslim adalah seluruh tubuh kecuali wajah.

Berdasarkan pendapat diatas, pendapat yang sesuai dengan keberadaan cadar adalah pendapat dari Imam Ahmad dalam salah satu riwayat, serta pendapat $\mathrm{Abu}$ Bakar dan Abd Rahman dari kalangan Tabi' in menyatakan bahwa seluruh tubuh dari perempuan Muslim adalah aurat, termasuk wajah dan telapak tangan.

Pilihan cadar sebagai bagian dari pakaian perempuan bercadar menjadi salah satu wujud dari cerminan konstruksi identitas yang dimiliki oleh seorang muslimah bercadar. Konstruksi identitas yang dibentuk oleh perempuan bercadar beserta dengan berbagai ciri khas yang melekat pada dirinya tidak selalu direpon positif oleh masyarakat secara luas hal tersebut dibuktikan melalui penelitian yang dilakukan oleh Tanra (2016) menunjukkan bahwa persepsi masyarakat terhadap perempuan bercadar itu sangat negatif dan juga mereka tidak menerima adanya perempuan bercadar di Desa mereka, bahkan sebagian masyarakat mengucilkan atau bahkan menolak keberadaan mereka dan mereka tidak di anggap di dalam masayarakat (Tanra, 2016). Namun ketika perempuan bercadar bertemu dengan sesama perempuan yang bercadar maka mereka akan merasa bahwa mereka adalah satu kelompok yang relative eksklusif meskipun masih tetap bergaul dengan masyarakat umum.

Diperlukan pemahaman bagi masyarakat untuk memahami perbedaan yang ada. Salah satu hal yang menjadi perhatian publik di tahun 2018 ini adalah fenomena mulai bermunculannya perempuan yang memutuskan untuk bercadar. Dilansir dari BCC Indonesia (2018) Rektor UIN Sunan Kalijaga, Yudian Wahyudi, mengatakan bahwa peningkatan jumlah mahasiswi bercadar yang menjadi puluhan menunjukkan gejala peningkatan radikalisme. Fenomena tersebut merupakan hal yang masih asing bagi beberapa kelompok masyarakat, sehingga direspon secara negatif. Selain itu belum banyak penelitian tentang pakaian sebagai salah satu wujud konstruksi identitas khususnya pada muslimah yang bercadar, namun sudah pernah dilakukan, tetapi dengan menggunakan sudut pandang sosiologi pada tahun 2013 di Kota Jember dengan narasumber yang sudah berkeluarga.

Penelitian ini bertujuan untuk mengetahui gambaran rekonstruksi identitas pada muslimah bercadar. Manfaat dari penelitian ini diharapkan mampu memberikan gambaran tentang konstruksi identitas muslimah bercadar secara lebih mendalam serta berdampak pada terwujudnya perilaku untuk saling menghargai antar individu sehingga terjalin hubungan yang harmonis di masyarakat. 


\section{METODE}

Rekonstruksi identitas didefinisikan sebagai pembentukan kembali sebuah pendefinisian diri baik secara pribadi (berkaitan dengan wujud atau tampilan fisik, pengolahan emosi, serta tingkah laku) maupun secara sosial (berkaitan dengan gambaran secara personal serta gender yang membentuk peran di masyarakat).

Jenis penelitian yang digunakan yaitu penelitian kualitatif dengan pendekatan fenomenologis. Menurut Sugiyono (2013) metode penelitian kualitatif merupakan sebuah metode penelitian yang digunakan untuk meneliti pada kondisi objek yang alamiah, (sebagai lawannya adalah eksperimen) dimana peneliti adalah sebagai instrumen kunci, teknik pengumpulan data dilakukan secara triangulasi (gabungan), analisis data bersifat induktif, dan hasil penelitian kualitatif lebih menekankan makna daripada generalisasi. Unit analisis yang akan diteliti berkaitan dengan identitas yang dimiliki oleh muslimah yang bercadar. Aspek-aspek yang akan diungkap adalah aspek identitas diri serta identitas sosial. Aspek identitas diri meliputi aspek fisik, kemampuan intelektual, emosi, sikap, dan nilai-nilai. Sedangkan aspek identitas sosial meliputi aspek self dan gender.

Tabel 1

Unit Analisis Penelitian

\begin{tabular}{|c|c|c|}
\hline $\begin{array}{l}\text { Sub Unit } \\
\text { Analisis }\end{array}$ & Aspek & Indikator \\
\hline Identitas & Fisik & 1. Gambaran tentang cara berpakaian yang benar. \\
\hline Diri & & 2. Gambaran tentang cara subjek berpakaian \\
\hline & & $\begin{array}{l}\text { 3. Gambaran tentang cara berpenampilan yang benar (aksesoris, warna, } \\
\text { dll.) }\end{array}$ \\
\hline & Kemampuan & 1. Pengetahuan tentang fungsi cadar. \\
\hline & Intelektual & 2. Pengetahuan tentang urgensi adanya hukum tentang aurat. \\
\hline & Emosi & 1. Perasaan sebelum dan setelah bercadar. \\
\hline & & $\begin{array}{l}\text { 2. Perasaan ketika subjek mendapat respon negatif dari masyarakat } \\
\text { dan/atau orang disekitar subjek. }\end{array}$ \\
\hline & & 3. Perasaan ketika melihat orang yang sama-sama memakai cadar. \\
\hline & & 4. Perasaan ketika melihat orang yang tidak menutup aurat dengan benar. \\
\hline & Sikap & 1. Cara subjek menyikapi respon negatif dari lingkungan. \\
\hline & & 2. Cara subjek dalam berinteraksi dengan lawan jenis selain muhrimnya. \\
\hline & Nilai-Nilai & 1. Keyakinan subjek tentang hukum bercadar. \\
\hline & & $\begin{array}{l}\text { 2. Kepercayaan subjek tentang agama dan prakteknya dalam kehidupan } \\
\text { sehari-hari }\end{array}$ \\
\hline & Pengaruh Keluarga & 1. Respon keluarga ketika subjek memutuskan untuk bercadar. \\
\hline & Pengaruh Budaya & $\begin{array}{l}\text { 1. Sudut pandang subjek tentang budaya jawa dan cara berpakaian orang- } \\
\text { orang jawa. }\end{array}$ \\
\hline & Pengaruh Gender & 1. Keyakinan tentang peran menjadi seorang perempuan. \\
\hline & $\begin{array}{l}\text { Pengaruh Orang } \\
\text { Lain }\end{array}$ & 1. Orang yang paling berpengaruh \\
\hline Identitas & Self & 1. Orang-orang dianggap sama dan berbeda dengan subjek \\
\hline Sosial & & $\begin{array}{l}\text { 2. Sudut pandang subjek tentang apa yang membedakan subjek dengan } \\
\text { orang yang tidak bercadar }\end{array}$ \\
\hline & Gender & 1. Peran sebagai perempuan secara sosial. \\
\hline & Pengaruh Keluarga & 1. Respon keluarga terhadap lingkungan yang kurang menerima subjek. \\
\hline & Pengaruh Budaya & 1. Kebiasaan lingkungan subjek tentang cara berpakaian. \\
\hline & $\begin{array}{l}\text { Pengaruh Orang } \\
\text { Lain }\end{array}$ & 1. Evaluasi Diri terhadap Orang Lain \\
\hline $\begin{array}{l}\text { digunaka } \\
\text { bercadar }\end{array}$ & $\begin{array}{l}\text { Imber data peneli } \\
\text { dalam penelitian } \\
\text { sebagai narasur }\end{array}$ & $\begin{array}{llll}\text { an yang akan } & \text { Sugiyono }(2014: 62) & \text { narasumber primer } \\
\text { lalah muslimah } & \text { merupakan narasumber yang memberikan } \\
\text { ber. Menurut } & \text { data langsung kepada pengumpul data. }\end{array}$ \\
\hline
\end{tabular}


Teknik sampling yang digunakan yaitu dengan menggunakan snowball sampling, menurut Sugiyono (2001:61), snowball sampling adalah teknik penentuan sampel yang mula-mula jumlahnya kecil kemudian sampel ini diminta untuk memilih orang lain untuk dijadikan sampel hingga jumlah sampel semakin banyak. Pemilihan narasumber primer dengan memerhatikan kriteria sebagai berikut: a) Seorang muslimah, b) Memakai cadar, c) Waktu memakai cadar antara 6 bulan hingga 2 tahun, d) Merupakan anggota dari komunitas $\mathrm{P}^{* * * * * * *}$, e) Usia dewasa awal (19-25 tahun)

Berdasarkan pendekatan yang dipergunakan dalam memperoleh data, maka teknik pengumpulan data yang dipergunakan adalah wawancara atau interview. Menurut Sugiyono (2013:34) "wawancara merupakan salah satu teknik pengumpulan data yang dapat dilakukan secara langsung berhadapan dengan yang diwawancarai".

Teknik analisis data yang digunakan oleh peneliti merupakan teknik analisis data melalui pendekatan fenomenologis dengan IPA (Interpretatif phenomenological analysis). IPA berfokus pada menafsirkan bagaimana partisipan sebagai orang yang mengalami langsung peristiwa tertentu untuk menafsirkan pengalamannya (Kahija, 2007:46). Adapun langkah-langkah analisis data menurut Kahija (2007:112) melalui beberapa tahap, yaitu tahap penghayatan transkrip dan pencatatan awal, tahap perumusan tema emergen, tahap perumusan tema superordinat, tahap pola-pola antarkasus atau antarpengalaman partisipan, dan tahap penataan seluruh tema superordinat

Sebagai wujud dari kredibitas penelitian, peneliti menggunakan kualitas penelitian dengan merujuk pada empat kualitas esensial yang dikemukakan oleh Yardley (dalam Kahija, 2017:201) yang relevan jika digunakan untuk penelitian fenomenologis. Empat kualitas esensial tersebut yaitu Sensitivitas terhadap konteks (sensitivity to context), komitmen dan keilmiahan (commitment and rigour), transparansi dan koherensi (transparency and coherence), dan dampak dan kebermanfaatan (impact and importance), penelitian mempunyai dampak secara teoritis, praktis, dan sosiokultural

\section{HASIL DAN PEMBAHASAN}

Penelitian ini menemukan beberapa tema yang menggambarkan rekonstruksi identitas pada muslimah bercadar sesuai dengan tujuan penelitian. Berikut adalah tema-tema superordinat yang ditemukan pada ketiga narasumber berkaitan dengan fungsi kognitif, perasaan, perilaku dan faktor yang mempengaruhi sebagai unsur-unsur yang membangun dinamika psikologi yang lengkap. Ditemukan lima tema yang menunjukkan fungsi kognitif pada muslimah bercadar. Pertama, pemikiran bahwa cadar sangat bermanfaat. Orientasi dari tujuan dan manfaat dari penggunaan cadar tidak terlepas dari laki-laki. FN mengungkapkan bahwa salah satu fungsi cadar adalah wajah nya tertutup dan tidak dilihat oleh laki-laki. Melalui fungsi tersebut terdapat kebermanfaat dari kedua belah pihak, yaitu pihak perempuan yang merasa lebih aman dan nyaman dan pihak laki-laki agar tidak memanjakan matanya untuk melihat perempuan.

Dari narasumber kedua yaitu LL mengungkapkan bahwa dengan bercadar ia meyakini laki-laki tidak akan menggoda karena muslimah bercadar tidak memiliki potensi untuk digoda. Potensi tersebut telah telah ditutup dengan menggunakan pakaian syar'i dan cadar. Perempuan diyakini sebagai fitnah terbesar laki-laki apabila laki-laki tidak mampu menjaga pandangannya ketika melihat perempuan, sehingga dalam hal ini cadar tidak hanya bermanfaat untuk perempuan, namun juga bermanfaat agar lakilaki dapat menjaga matanya. Hal tersebut 
sesuai dengan pernyataan yang disampaikan oleh LL berikut:

"Laki-laki kan gak mungkin ngegoda perempuan kalo dia nggak ada potensi untuk digoda, kan kalo misalkan ditutup gak ada potensi untuk digoda kayak gitu, kayak gitu, terus ya, ada beberapa kasus juga yang intinya aku tuh diliatin dan aku nggak suka gitu, aku tuh emosi, kayak gitu. Jadi aku lebih memilih buat menjaga kedamaian hatiku ketimbang aku emosi karena digoda dan menjaga laki-laki buat nggak ngeliat karena aku juga salah satu apa, salah satu sumber fitnah utama bagi dia gitu, jadi maksud dari wanita menjadi fitnah bagi laki-laki ya itu” (LL, 124-131)

\section{Ketiga narasumber merasa mendapatkan ketenangan dengan tidak menarik perhatian sehingga tidak diganggu dan digoda oleh laki-laki, hal tersebut diyakini karena dengan menggunakan cadar maka akan menutup bagian wajah dan penggunaan pakaian yang syar'i tidak akan mengundang perhatian laki-laki. FN juga meyakini bahwa dengan menggunakan cadar dan pakaian yang syar' $i$ maka akan membantu pihak laki-laki untuk menjaga pandangan.}

Kedua, ketaatan terhadap hukum agama semakin kuat. Narasumber ketiga yaitu MI menyatakan bahwa cara berpakaian yang sesuai syariat adalah pakaian yang menutup aurat. Aturan tersebut telah tertulis di dalam Al-Qur'an, bahwa bagian tubuh wanita yang boleh terlihat yaitu hanya bagian telapak tangan dan muka, selain kedua bagian tersebut maka tidak boleh terlihat oleh lakilaki yang bukan muhrim. Kriteria pakaian yang syar'i yaitu pakaian yang menutup hingga ujung kaki, tidak membentuk lekuk tubuh, tidak tipis dan penggunaan kerudung yang minimal menutup bagian dada. Temuan tersebut didukung dengan pernyataan yang disampaikan oleh MI, yaitu:

"Pakaian yang sesuai dengan
syariat itu adalah pakaian yang
menutup aurat, disini, apa.. aurat
itu udah disebutkan di dalam Al-
Qur'an ya, yang musti ditutup
apa aja, kalau wanita itu yang
boleh terlihat adalah telapak
tangan sama muka, itu sih, sama
kalo hijab, kalau yang namanya
jilbab itu sebenernya pakaian
yang dari leher sini sampai ke
ujung kaki, terus jilbab, namanya
jilbab tuh itu, terus kalo yang
khimar, yang atasan, kan kita
terpisah khimarnya, itu yang
menutup, apa yang syar'i itu
batas minimal menutup dada,
dan apa... ee.....pakaiannya...satu
nggak boleh tipis dan nrawang,
dua dia nggak boleh membentuk
lekuk tubuh, kayak yang terlalu
ketat, gitu, insyaallah itu udah
syar'i" (MI, 1-10)

Muslimah bercadar tidak hanya berfokus pada pemakaian cadar saja, namun juga dalam berpakaian. Ketiga narasumber yaitu FN, LL, dan MI menunjukkan ketaatan terhadap hukum agama yang semakin kuat terutama dalam hal cara berpakaian. Mereka menggunakan Al-Qur'an sebagai pedoman dalam cara berpakaian yang sesuai dengan syariat.

Ketiga, keinginan berbuat baik agar mendapatkan surga. Surga menjadi impian dari sebagian besar seorang muslim, tidak terkecuali seorang muslimah bercadar. FN menunjukkan caranya untuk mencapai surga dengan bersungguh-sungguh dalam bertaqwa serta beriman kepada Allah. FN sangat meyakini bahwa ketika ia sudah menunjukkan ketaqwaan dan keiminannya sehingga Allah, mengijinkan maka tidak ada yang tidak mungkin, seperti pernyataan FN berikut:

"Saya mau masuk apa,mau

masuk surga ya harus menyelamatkan agamanya Allah, 
buat nuntun orang-orang juga, kalo Islam itu juga baik gitu, baik bener-bener baik gitu, kamu bisa kalo kamu bener-bener taqwa sama Allah, bener-bener beriman sama Allah, kamu bisa ngedapetin semuanya yang diijinin sama Allah itu bisa" (FN, 201-205)

Tujuan akhir dari ketaatan yang kuat adalah untuk kepentingan akhirat yaitu agar mendapatkan surga. FN dan MI meyakini bahwa dengan menyelamatkan agama Allah maka akan mendapatkan imbalan yaitu masuk ke surga, sedangkan melakukan hijrah sebagai cara untuk mendapatkan surga. Bentukbentuk perilaku untuk mencapai surga akan membentuk sebuah sikap yang berkaitan dengan etika individu dalam bertingkah laku sehari-hari.

Keempat, pengalaman buruk dengan laki-laki hingga mengenal cadar. Seorang muslimah bercadar tidak terlepas dari hubungan dengan laki-laki. FN mengaku pernah menjalin hubungan yang cukup dekat dengan seorang laki-laki namun tidak memiliki status pacar. Berdasarkan keterangan dari FN, laki-laki tersebut sempat menyatakan perasaannya kepada $\mathrm{FN}$, namun FN tidak menerima nya sebagai pacar.

Hubungan dengan laki-laki tersebut tidak berakhir dengan baik. FN menganggap laki-laki tersebut adalah laki-laki yang tidak baik dan kasar, meski awalnya FN masih tetap menjalin hubungan dengan laki-laki tersebut akhirnya ia memutuskan untuk menjauhi dan berhenti berhubungan dengannya. Sikap kasar dan tidak baik dari laki-laki tersebut dianggap sebagai petunjuk dari Allah yang disampaikan melalui perilaku lakilaki tersebut. Hal tersebut sesuai dengan pernyataan yang disampaikan oleh FN sebagai berikut:

"Sebenernya tuh kalau dibilang pernah deket sama cowok itu pernah mbak gitu, cuma ngga ada hubungan apa-apa, pernah ana ditembak tapi ana nggak mau, tau ana nggak boleh gitu, Cuma ana gak berpikir ana deket sama cowok juga gak boleh gitu, jadi kalau itu deket sama cowok, udah dikasih tau sama Allah, udah dikasih jawaban sama Allah buat kamu seharusnya ngejauhin gitu, tapi ana nya yang bandel gitu, masih deket deket deket deket gitu, udah dikasih jawaban kalau cowok itu tu nggak baik buat kamu. Dia tuh aslinya kayak gini, kasar, apa apa, udah dikasihjawaban gitu, ana nya aja yang nggak ngejauh" (FN, 328-336)

FN dan MI mengaku tidak pernah menjalin hubungan pacaran, namun mereka pernah menjalin hubungan dekat dengan lakilaki. MI menegaskan bahwa ia pernah merasa hampir terjerumus dalam hubungannya dengan seorang laki-laki. Berbeda dengan narasumber kedua yaitu yang mengaku bahwa dirinya pernah menjalani sebuah hubungan pacaran dengan seorang laki-laki. Ketiga narasumber menunjukkan perubahan tersebut dengan lebih berhati-hati dengan memberikan batasan yang jelas ketika berhubungan dengan laki-laki, dan tentunya batasanbatasan tersebut dilandasi oleh Al-Qur'an.

Kelima, meneladani kepribadin rasul dan sahabat rasul. MI menjadikan Nabi Muhammad SAW sebagai tauladan dalam hidupnya. MI lebih lanjut menjelaskan bahwa ia mempelajari sikap dan perilaku Rasulullah dengan cara mendengarkan sejarah nabi, karena MI meyakini bahwa permasalahan yang ada saat ini tidak berbeda jauh dengan peristiwa yang pernh terjadi pada masa Rasulullah. Dengan meneladani kisah-kisah di jaman Rasulullah, MI menjelaskan bahwa orang-orang yang hidup di jaman tersebut (Rasulullah, istri Rasulullah dan sabahat Rasulullah) menyelesaikan permasahalannya sesuai dengan hukum-hukum Islam, sehingga 
hal tersebut dapat dijadikan sebagai tauladan dalam menyelesaikan sebuah permasalahan. MI menjelaskan hal tersebut melalui pernyataan berikut:

"Kaloo... tauladan ya.. pasti
tauladannya ya Rasulullah itu,
kalo kita kan perempuan ya, ana
sih suka dengerin siroh, tau siroh
nabawiyah kan.. ya itu, ana dari
situ.. pertama kali ana hijrah kan
memang dari dengerin itu, kayak,
kayak sebenernya tuh semua
masalah yang ada di kita
sekarang ini, itu tu udah dialami
dari para, para pendahulu kita
itu lho, apalagi mereka adalah
orang-orang yang hidup
dijamannya Rasulullah, udah tau
hukum-hukum nya, jadi ana lebih
suka dengerin kisahnya mereka,
jadi dari situ kayak mereka tuh
jadi tokoh-tokoh panutan ana
dalam menyikapi nek misal ada
kayak gini harus gimana" (MI,
215-223)

Ketiga narasumber mengaku bahwa mereka menjadikan Nabi Muhammad SAW adalah tauladan dalam menjalani hidup. FN dan MI menganggap bahwa Rasulullah memang merupakan tauladan bagi seluruh umat Islam, sedangkan LL menganggap Rasulullah sebagai tauladan serta menjadi idola. Istri serta sahabat Nabi juga menjadi contoh yang baik dalam bersikap serta menyelesaikan permasalahan.

Ditemukan satu tema yang berkaitan dengan perasaan muslimah bercadar yaitu Perasaan lebih nyaman ketika bercadar. Hasil temuan terkait tema tersebut adalah sebagai berikut:

Muslimah bercadar tetap mempertahankan identitasnya salah satunya karena merasa nyaman dengan cara berpakaiannya. LL mengaku bahwa dirinya merasa lebih nyaman setelah memutusakn untuk bercadar. LL secara lebih lanjut menjelaskan bahwa perasaan nyaman tersebut timbul karena ada perasaan kedamaian. LL membandingkan dengan perasaannya sebelum hijrah, yaitu ketika masih berpacaran ia merasa lebih gelisah dan membuatnya merasa tidak nyaman. Perasaan lebih nyaman tersebut sesuai dengan pernyataan LL berikut:

"Kalau dari perasaanya itu jelas lebih nyaman, maksudnya hijrah itu kan tujuannya untuk mencari kedamaian, kalo aku sendiri, maksudnya kayak ketika belum hijrah ketika masih pacaran itu hati tuh sangat gelisah gitu loh, ketakutan" (LL, 133-136)

Ketiga narasumber mengaku merasa nyaman ketika menggunakan cadar, sehingga menjadi dasar mereka untuk mengambil keputusan untuk bercadar sehingga menunjukkan perilaku yang secara tidak langsung dituntut untuk berperilaku lebih baik dimata masyarakat.

Ditemukan satu tema yang berkaitan dengan perilaku muslimah bercadar yaitu Berperilaku sebaik mungkin dan mengajak orang lain. Hasil temuan terkait tema tersebut adalah sebagai berikut :

MI berusaha untuk tetap rendah hati dengan cara menyembunyikan amal ibadah yang telah dilakukannya. MI berusaha untuk selalu menata niatnya agar tidak menjadi pamer, salah satunya dengan cara tidak menunjukkan atau menyembunyikan amal ibadahnya. MI menjelaskan bahwa ia memiliki kekhawatiran jika ia memiliki niat yang kurang tepat ketika menunjukkan amal ibadah yang dilakukannya. Hal tersebut disampaikan oleh MI sebagai berikut:

"Sekarang udah berusaha biar ndak. piye carane satu. apa.. menyembunyikan amal ibadah.. yo kayak.. yooo... nek dulu kan mungkin, yo mengajak itu baik, niatnya kan seng penteng di lurusin dulu.. kalau ngajak misal bersodaqoh. itu kan baik.. syiar.. cuman kalau.. kalau kita infaq atau sodaqoh dengan sendiri itu kayaknya pengennya di 
sembunyiin aja gitu loh. takut nek. . niat $k u$, takut nek niatku sendiri salah" (MI, 780-786)

Perilaku yang ingin ditunjukkan oleh LL yaitu dengan memberikan sebuah pembuktian, pembuktian tersebut ditunjukkan dengan akhlak yang baik. LL menunjukkan perannya sebagai muslimah bercadar dengan hak-hak normatifnya untuk melakukan dakwahnya, namun juga berkewajiban untuk tidak hanya berdakwah melalui mulut saja, namun juga melalui akhlak yang baik. FN dan MI juga memiliki hak-hak normatifnya untuk melakukan dakwah baik secara langsung maupun melalui media sosial.

Ditemukan tiga tema yang berkaitan dengan faktor yang mempengaruhi dari luar atau faktor eksternal muslimah bercadar. Pertama, keluarga yang memahami keputusan untuk bercadar. Keluarga menjadi salah satu faktor yang mempengaruhi karena merupakan lingkungan terdekat individu, tidak terkecuali pada seorang muslimah yang bercadar. FN merasa bahwa awalnya keluarga menjadi salah satu faktor yang kurang mendukung akan pilihan identitas barunya untuk menjadi seorang muslimah bercadar. Saat ini orang tua FN sudah mulai memahami keputusan FN untuk bercadar dengan tetap memberikan pesan agar tidak berlebihan, seperti yang dikatakan FN berikut ini:

"Menghambat, maksude kayak
nggak direstui sih mbak, nggak
tau ya, tapi akhir-akhir ini tuh
cuma kayak ibu tuh paling kayak
ya jangan berlebihan lah, cuma
bilang gitu tok, tapi selanjute
dibiarin aja, cuma dibilangin
gitu tok, nanti pas, oh yaudah,
gitu sih" (FN, 557-559)

Keluarga menjadi salah satu faktor yang mempengaruhi pilihan akan identitas seorang muslimah bercadar. Ketiga narasumber awalnya tidak mendapatkan dukungan dari dari keluarga namun akhirnya keluarga mampu memahami keputusan narasumber untuk bercadar. FN sebagai narasumber pertama mengaku pernah memutuskan untuk tidak bercadar lagi karena tidak diijinkan oleh orang tua, pada saat itu FN merasa bimbang akan keputusan yang akan diambil namun perlahan keluarga FN mulai memahami keputusan narasumber untuk bercadar. LL awalnya juga ditentang oleh orang tua, namun sekarang sudah mulai diijinkan. Narasumber ketiga yaitu MI masih tidak diijinkan bercadar oleh orang tuanya, namun diijinkan apabila juga diijinkan oleh suami MI. Ketika melakukan wawancara kedua, MI sudah bersuami dan diijinkan oleh suami, namun MI mengaku akan tetap melepaskan cadar apabila sedang dalam acara keluarga besar meskipun telah diijinkan oleh suami. Hal tersebut dilakukan oleh MI karena ia tidak ingin merusak suasana jika bercadar di tengah acara keluarga.

Kedua, pengaruh komunitas dakwah P****** yang cukup kuat. MI menyebut bimbingan dalam komunitas dengan nama kholaqoh. Ia menambahkan bahwa dalam kholaqoh tersebut terdapat pembina, pembina dalam kholaqoh adalah seorang tokoh ulama atau ustadz. MI menganggap bahwa sebagai anggota komunitas yang akan mengurus berjalannya sebuah kajian, maka harus memahami materi yang akan disampaikan dalam kajian. Adanya kholaqoh bertujuan untuk memberikan ilmu yang akan disampaikan pada kajian, sehingga ketika mengurus kajian, sehingga pengurus kajian tetap akan mendapatkan ilmu yang sama di kajian, seperti yang disampaikan oleh MI sebagai berikut:

"Kholaqoh kayak bimbingan, kan setiap itu ada pembinanya to, pembinanya biasanya tokoh ulama, atau ustadz kayak gitu gitu, nah itu, mereka itu ikhtiarnya biar, gini lho, kan kita.. misal coro-corone kita punya acara seminar lah, panitia, lha kan kita kan kadang 
sibuknya tuh sibuknya ngurusi, ngurusi acara, bahkan sampe nggak dengerin materi, pernah kan, pernah kan kayak gitu, nah itu coro-corone kalau filosofi itu jangan sampe kita itu jadi seperti lilin gitu loh, yang memberikan cahaya buat yang lain tapi terbakar, habis, nah jangan sampe kita ngadain yang alhamdulillah mungkin bermanfaat, insyaallah bermanfaat untuk umat tapi kita nggak dapet ilmunya karena memang kan, apalagi tim kan ngurusi jamaah" (MI, 15741584)

Tidak berbeda jauh dengan MI, LL menyatakan bahwa di dalam komunitas tersebut terdapat bimbingan. Bimbingan diberikan kepada anggota komunitas yang nantinya akan menjadi panitia yang mengurus berjalannya sebuah kajian. Begitu pula FN, berdasarkan keterangan dari $\mathrm{FN}$, ia mendapatkan banyak ilmu terkait cara berpakaian yang benar, akidah dan akhlak. Ilmu yang didapatkan dari komunitas dirasa cukup meyakinkan untuk dipercaya oleh FN. Ketiga narasumber juga mengikuti sebuah komnitas yang sama, dimana komunitas tersebut dianggap sebagai sebuah tim dakwah.

Ketiga, lingkungan pertemanan, tetangga dan masyarakat umum yang kurang mendukung. Salah satu faktor lain selain keluarga dan komunitas, terdapat lingkungan tetangga yang dekat dengan lingkungan keluarga serta masyarakat umum. LL merasa bahwa lingkungan tetangga masih banyak yang tidak menjalankan perintah dalam agama Islam. LL menjelaskan bahwa lingkungan tetangga dianggap sudah tau tentang aturan dari Allah namun tidak dijalankan dengan baik. Masih terdapat tetangga yang tidak menutup aurat ketika keluar rumah. LL juga pernah di anggap sebagai wahabi oleh tetangganya, namun LL tidak terlalu memikirkan komentar tersebut.
Hal tersebut sesuai dengan pernyataan LL berikut:

"Kalau tetangga sih, karena emang tetangga tuh... pck... bisa dikatakan masih sekuler, sekuler itu ada aturan dari Allah tapi tidak mejalankan, jadi masih banyak yang belom pake, pake kerudung, maksudnya kan, kalo yang namanya orang udah ngerti aurat harus ditutup, kalo keluar rumah mau ke warung kan tetep pake ya, karena itu kan aurat, nah sedangkan tuh masih banyak yang nggak pakejadi ketika aku pake cadar mungkin kayak, tuh $l^{* * *}$ kenapa? gitu, terus pernah juga aku tuh dibilang, salah satu kaum yang, ya gitulah disebut, mbak $l^{* * *}$ kok pake cadar? kayak wahabi, kayak gitu, batinku, lha wahabi ki opo ?? gitu hahahaa... apakah dia tau wahabi" (LL, 955-964)

LL juga merasa bahwa lingkungan tetangga masih banyak yang tidak menjalankan perintah dalam agama Islam. LL menjelaskan bahwa lingkungan tetangga dianggap sudah tau tentang aturan dari Allah namun tidak dijalankan dengan baik. Masih terdapat tetangga yang tidak menutup aurat ketika keluar rumah. LL juga pernah di anggap sebagai wahabi oleh tetangganya, namun LL tidak terlalu memikirkan komentar tersebut.

Pada identitas yang dibangun oleh muslimah bercadar terbentuk menjadi identitas diri dan identitas sosial. Berdasarkan analisis IPA (Interpretative Phenomenological Analysis) ditemukan identitas diri yang diwujudkan dalam bentuk kognitif dan afektif. Secara kognitif, pemikiran-pemikiran yang mendukung identitas muslimah bercadar adalah terkait dengan kebermanfaatan cadar, sehingga membuat mereka merekonstruksikan dirinya sebagai muslimah bercadar dengan meyakini banyaknya manfaat yang diperoleh dari cadar. 
Didukung dengan identitasnya sebagai muslimah yang taat terhadap hukum agama untuk mendapatkan surga dengan berbuat baik sesuai dengan Rasul dan sahabat Rasul sebagai tauladan hidup. Pengalaman buruknya dengan laki-laki membuatnya ingin menjaga diri dari laki-laki dengan cara bercadar. Secara afektif, narasumber merasa nyaman dengan identitasnya sebagai muslimah bercadar. Identitas sosial yang dibangun oleh muslimah bercadar adalah menjadi anggota masyarakat dengan tuntutan berperilaku sebaik mungkin dan mengajak orang lain untuk menjadi individu yang lebih baik menurut versinya. Sebagai muslimah bercadar yang menjadi kaum minoritas di tempat tinggalnya, mereka menyadari bahwa ada banyak sudut pandang negatif dari masyarakat yang harus diterima.

Secara umum terdapat sepuluh temuan yang ditemui di ketiga narasumber, yaitu pemikiran bahwa cadar sangat bermanfaat, ketaatan terhadap hukum agama yang semakin kuat, keinginan berbuat baik agar mendapatkan surga, pengalaman buruk dengan laki-laki hingga mengenal cadar, meneladani rasul dan sahabat rasul, perasaan lebih nyaman ketika bercadar, berperilaku sebaik mungkin dan mengajak orang lain, keluarga yang kurang mendukung, pengaruh komunitas dakwah $\mathrm{P} * * * * * *$ yang cukup kuat, dan lingkungan pertemanan, tetangga dan masyarakat umum yang kurang mendukung.

Barker (2004) menyatakan bahwa identitas merupakan sebuah konstruksi diskursif yang berubah maknanya menurut ruang, waktu dan pemakaian. Perubahan tersebut terjadi pada ketiga narasumber, khususnya berkaitan dengan hubungan antara laki-laki dan perempuan. FN dan MI mengaku tidak pernah menjalin hubungan pacaran, namun mereka pernah menjalin hubungan dekat dengan laki-laki. MI menegaskan bahwa ia pernah merasa hampir terjerumus dalam hubungannya dengan seorang laki-laki. Berbeda dengan narasumber kedua yaitu LL yang mengaku bahwa dirinya pernah menjalani sebuah hubungan pacaran dengan seorang laki-laki. Ketiga narasumber menunjukkan perubahan tersebut dengan lebih berhati-hati dengan memberikan batasan yang jelas ketika berhubungan dengan laki-laki, dan tentunya batasan-batasan tersebut dilandasi oleh AlQur'an. Ketika sedang dekat dengan laki-laki, FN merasa diperlakukan secara tidak baik bahkan kasar, namun FN yakin hal tersebut adalah petunjuk yang diberikan oleh Allah bahwa laki-laki yang dahulu dekat dengan FN bukanlah orang yang baik untuk FN. Hal tersebut sesuai dengan hasil penelitian yang dilakukan oleh Utami (2012) bahwa salah satu aspek koping religiusitas yaitu Collaborative Religious Coping : mencari kontrol melalui hubungan kerjasama dengan Allah dalam pemecahan masalah, ketika sedang menghadapi masalah individu mampu berusaha, berdoa dan merasa mendapatkan bimbingan dari Allah.

Ketiga narasumber memiliki keinginan terhadap diri yang sesuai yaitu keinginan untuk menjaga diri dari pandangan laki-laki, dimana ketiganya memiliki pengalaman kurang baik dengan laki-laki. Pengalaman tersebut membuat masingmasing dari mereka membutuhkan perlindungan lebih dari pandangan laki-laki. Penelitian yang dilakukan oleh Rahmawati (2017) menemukan bahwa sense of community dapat berfungsi untuk membentuk perasaan sejahtera secara psikis dalam menghuni (housing well-being). Perasaan terlindungi dari laki-laki muncul setelah narasumber meghuni atau menjadi bagian dari komunitas dan mendapatkan pengetahuan dari komunitas bahwa dengan bercadar akan membuat mereka lebih terlindungi, perasaan terlindungi yang dimaksud berkaitan dengan perasaan terlindungi dari godaan dan tatapan laki-laki yang bukan muhrim, sehingga peranan anggota komunitas sangat terasa dan semakin diperkuat dengan adanya bimbingan 
rutin seminggu sekali. Hal tersebut sesuai dengan hasil penelitian yang dilakukan oleh Falatehan (2017) bahwa perasaan yang cukup kuat sebagai anggota dengan membagi keyakinan bersama bahwa kebutuhan anggota kelompok dapat dipenuhi selama berkomitmen untuk dalam keadaan berkelompok.

Ketiga narasumber merasa mendapatkan ketenangan dengan tidak menarik perhatian sehingga tidak diganggu dan digoda oleh laki-laki, hal tersebut diyakini karena dengan menggunakan cadar maka akan menutup bagian wajah dan penggunaan pakaian yang syar'i tidak akan mengundang perhatian laki-laki. FN juga meyakini bahwa dengan menggunakan cadar dan pakaian yang syar'i maka akan membantu pihak laki-laki untuk menjaga pandangan. Hal tersebut menunjukkan bahwa kebermanfaatan cadar tidak hanya untuk pihak perempuan sebagai pemakai, namun juga untuk pihak laki-laki. Hal ini sesuai dengan hasil penelitian yang dilakukan oleh Nurhayat (2018) yaitu aturan mengenai cadar diatur oleh Allah di Al-Qur'an yang bertujuan untuk melindungi dan menjauhkan wanita dari gangguan nafsu dan tatapan buruk pria. LL meyakini bahwa tubuh wanita sangat berpotensi untuk digoda oleh laki-laki, sehingga berpakaian syar'i dan bercadar merupakan alteratif solusi untuk menutup tubuh wanita dengan benar agar tidak digoda oleh lawan jenis. Ketika tidak digoda oleh lawan jenis, maka LL mengaku bahwa ia akan merasa lebih tenang, karena LL merasa emosi apabila dilihat terlalu lama oleh laki-laki. Di sisi lain, LL merasa bahwa sebenarnya cadar juga bermanfaat untuk lawan jenis, dimana ia meyakini bahwa perempuan merupakan salah satu fitnah (godaan) bagi laki-laki, sehingga keberadaan cadar juga untuk membantu lakilaki untuk menjaga pandangannya. Manfaat cadar untuk menghindari godaan dari laki-laki dirasakan oleh ketiga narasumber termasuk narasumber ketiga yaitu MI, namun pada kenyataannya MI masih merasakan godaan dari laki-laki namun dalam bentuk yang berbeda dan lebih sopan yaitu dengan mengucapkan "Assalamualaikum" kepadanya, hal tersebut menunjukkan bahwa cadar juga dapat menjadi identitas sebagai seorang muslim. Penelitian yang dilakukan oleh Rasyid (2018) yang menyebutkan bahwa cadar dimaksudkan sebagai identitas bagi perempuan muslim dan merdeka.

Identitas sebagai seorang muslimah bercadar di usia yang sudah memasuki usia dewasa awal menjadi hal yang penuh dengan pertimbangan. Keluarga menjadi salah satu faktor yang dipertimbangkan dalam pemilihan akan identitas barunya sebagai seorang muslimah bercadar. Ketiga narasumber awalnya tidak mendapatkan dukungan dari dari keluarga. FN sebagai narasumber pertama mengaku pernah memutuskan untuk tidak bercadar lagi karena tidak diijinkan oleh orang tua, pada saat itu FN merasa bimbang akan keputusan yang akan diambil. LL sebagai narasumber kedua juga awalnya tidak diberikan ijin oleh kedua orang tuanya. Hal tersebut sejalan dengan penelitian yang dilakukan oleh Putra (2011) pada sopir bus malam, dimana semakin tinggi dukungan sosial keluarga, maka semakin rendah stress kerja pada sopir bus malam. Awalnya LL bimbang dengan keputusannya dengan identitas barunya sebagai seorang muslimah bercadar, namun LL mendapatkan penguatan dari komunitas terkait tujuan dari bercadar demi kebaikan kedua orang tua narasumber maka LL berusaha untuk meyakinkan kedua orang tua dengan menunjukkan perilaku atau akhlak yang lebih baik dibandingkan sebelum bercadar, sehingga sekarang ibu narasumber telah memberikan ijin kepada narasumber untuk bercadar bahkan berdasarka keterangan dari narasumber, ibu narasumber merasa senang dengan keputusannya untuk bercadar karena bertujuan untuk menjaga diri. Ijin dan respon positif dari ibu narasumber akhirnya membuat narasumber menjadi semakin yakin 
akan identitas barunya sebagai seorang muslimah yang bercadar. Hal tersebut juga sesuai dengan hasil penelitian yang dilakukan oleh Desiningrum (2010) pada lansia, yaitu dukungan sosial dari keluarga memberikan kontribusi tinggi terhadap kesejahteraan psikologis. Narasumber ketiga yaitu MI awalnya juga tidak diijinkan bercadar oleh orang tuanya, namun akan diberikan ijin apabila juga diijinkan oleh suami MI. Ketika melakukan wawancara kedua, MI sudah memiliki suami dan suami MI memberika ijin MI untuk bercadar, namun MI mengaku akan tetap melepaskan cadar apabila sedang dalam acara keluarga besar meskipun telah diijinkan oleh suami. Hal tersebut dilakukan oleh MI karena ia tidak ingin merusak suasana jika bercadar di tengah acara keluarga.

Santrock (2007) menyebutkan bahwa keluarga menjadi salah satu faktor yang mempengaruhi pembentukan identitas yaitu individualitas dan keterjalinan. Individualitas dibagi menjadi dua, yaitu pernyataan diri serta keterpisahan. Ketiga narasumber mengungkapkan pernyataan dirinya sebagai muslimah bercadar yang akan tetap menjadi diri mereka sendiri serta keterpisahan mereka yaitu mereka berbeda dengan golongan ekstremis. Keterjalinan juga dibagi menjadi dua, yaitu sensitivitas dan penghargaan terhadap pandangan orang lain. Sensitivitas ketiga narasumber terletak pada hubungan dengan lawan jenis, dimana jika tidak menutup wajahnya maka mereka akan merasa diperhatikan oleh laki-laki. Penghargaan terhadap pandangan orang lain dilakukan oleh ketiga narasumber pada pandanganpandangan yang dianggap sesuai dengan konsep berpikir mereka. Bersarnya pengaruh dari keluarga didukung oleh hasil penelitian Deliana dan Sunuhadi (2013) yaitu faktor yang cenderung sangat berpengaruh adalah faktor keluarga, lingkungan teman sebaya dan media teknologi informasi dan komunikasi, serta pengalaman masa lalu.
Muslimah bercadar tidak hanya berfokus pada pemakaian cadar saja, namun juga dalam berpakaian secara lebih menyeluruh. Setelah ketiga narasumber yaitu FN, LL, dan MI menjadi seorang muslimah bercadar, mereka menunjukkan ketaatan terhadap hukum agama yang semakin kuat terutama dalam hal cara berpakaian. Mereka menggunakan Al-Qur'an sebagai pedoman dalam cara berpakaian yang sesuai dengan syariat. LL meyakini bahwa di dalam Islam telah mengatur cara berpakaian, dengan aturan menggunakan pakaian yang longgar dan kerudung yang menutup bagian dada. MI juga menyatakan hal yang sama secara lebih detail bahwa di dalam Al-Qur'an telah menjelaskan bahwa aurat perempuan adalah seluruh tubuh kecuali wajah dan telapak tangan dengan pemilihan pakaian yang tidak tipis dan tembus pandang, serta tidak membentuk lekuk tubuh. Hal tersebut diperkuat dengan seruan ulama-ulama tentang perempuan agar menggunakan pakaian yang sesuai dengan syariat. Yusuf (2004:203) menjelaskan bahwa kemampuan intelektual sebagai salah satu bagian dari aspek identitas diri berkaitan dengan fungsi kognitif individu dalam memproses informasi yang masuk untuk selanjutnya diputuskan untuk diterima atau ditolak. Keputusan tersebut diambil oleh ketiga narasumber apabila diperkuat dengan ayat-ayat Al-Qur'an, hadist, serta pendapatpendapat tokoh agama yang dipercaya. Hal tersebut juga berkaitan dengan aspek nilainilai dalam identitas diri dalam Yusuf (2004:203), nilai-nilai berkaitan dengan kepercayaan yang diyakini oleh individu dalam menjalani hidupnya. Nilai-nilai yang dipegang kuat oleh seorang muslimah bercadar berkaitan dengan ayat-ayat di dalam Al-Qur'an. Kepercayaan tersebut tentunya tidak muncul dengan sendirinya, dalam penelitian yang dilakukan oleh Putra dan Maria (2008) menyatakan bahwa sesuatu hal tidak akan muncul jika hal tersebut tidak 
dibangun karena memang tidak diinginkan dan tidak dipikirkan.

Tujuan akhir dari ketaatan yang kuat adalah untuk kepentingan akhirat yaitu agar mendapatkan surga. FN menunjukkan caranya untuk mencapai surga dengan bersungguh-sungguh dalam bertaqwa serta beriman kepada Allah. FN sangat meyakini bahwa ketika ia sudah menunjukkan ketaqwaan dan keimanannya sehingga Allah, mengijinkan maka tidak ada yang tidak mungkin. MI meyakini bahwa segala perbuatan di dunia apabila diniatkan untuk berdakwah maka akan pahala akan disalurkan ke akhirat, sedangkan LL melakukan hijrah sebagai cara untuk mendapatkan surga, LL meyakini bahwa dosa menjadi penghambat serta penghalang dari terkabulnya sebuah doa, tidak terkecuali doa untuk masuk ke surga, oleh sebab itu LL memilih untuk berhijrah serta berusaha untuk tidak melakukan perbuatan yang menimbulkan dosa. Bentukbentuk perilaku untuk mencapai surga akan membentuk sebuah sikap yang berkaitan dengan etika individu dalam bertingkah laku sehari-hari. Hal tersebut merupakan salah satu aspek identitas diri menurut Yusuf (2004) yaitu aspek sikap. LL berdoa agar kelak di akhirat mendapatkan surga, dan melakukan hijrah untuk mengurangi dosa sehingga doa dapat lebih mudah terkabul. Hal tersebut sesuai dengan hasil penelitian yang dilakukan oleh Nusawakan, Ranimpi, \& kawonal (2012) yaitu hubungan dengan Tuhan diekspresikan melalui doa dan pengabdian dalam kehidupan sesehari.

Ketiga narasumber mengaku bahwa mereka menjadikan Nabi Muhammad SAW adalah tauladan dalam menjalani hidup. FN dan MI menganggap bahwa Rasulullah memang merupakan tauladan bagi seluruh umat Islam, sedangkan LL menganggap Rasulullah sebagai tauladan serta menjadi idola. Rasulullah memiliki ketampanan yang berkali-kali lipat jika dibandingkan dengan bulan. Secara kepribaidan, Rasulullah telah memberikan contoh sikap sebagai anak yang baik kepada orang tua. MI lebih lanjut menjelaskan bahwa ia mempelajari sikap dan perilaku Rasulullah dengan cara mendengarkan sejarah nabi, karena MI meyakini bahwa permasalahan yang ada saat ini tidak berbeda jauh dengan peristiwa yang pernh terjadi pada masa Rasulullah. Dengan meneladani kisah-kisah di jaman Rasulullah, MI menjelaskan bahwa orang-orang yang hidup di jaman tersebut (Rasulullah, istri Rasulullah dan sabahat Rasulullah) menyelesaikan permasahalannya sesuai dengan hukum-hukum Islam, sehingga hal tersebut dapat dijadikan sebagai tauladan dalam menyelesaikan sebuah permasalahan. Istri serta sahabat Nabi juga menjadi contoh yang baik dalam bersikap serta menyelesaikan permasalahan. Hal tersebut sesuai dengan hasil penelitian yang dilakukan oleh Taklimudin dan Saputra (2018) yaitu beberapa ayat Al-Qur'an yang digunakan sebagai landasan normatif digunakan sebagai metode keteladanan dalam pendidikan Islam, deskripsi normatif tersebut secara eksplisit memberikan gambaran adanya keteladanan yang dicontohkan oleh para Nabi dan Rasulullah SAW serta para sahabat digunakan sebagai pijakan dan sandaran oleh para praktisi.

Salah satu aspek identitas diri adalah aspek emosi, menurut Yusuf (2004) emosi berkaitan dengan perasaan individu dan menjadi dasar seorang individu dalam bertingkah laku, berinteraksi dengan orang lain, berkarya dan berpengaruh terhadap perasaan bahagia atau tidak bahagia. Ketiga narasumber mengaku merasa nyaman ketika menggunakan cadar, sehingga menjadi dasar mereka untuk mengambil keputusan untuk bercadar sehingga menunjukkan perilaku yang secara tidak langsung dituntut untuk berperilaku lebih baik dimata masyarakat. Perasaan nyaman yang dirasakan oleh FN adalah karena ia tidak menjadi perhatian lakilaki setelah menggunakan pakaian syar'i dan 
bercadar. Berdasarkan keterangan dari FN, ketika ia masih menggunakan pakaian yang tidak menutupi bagian dada, ia masih merasa diperhatikan oleh laki-laki, sehingga hal tersebut membuat FN merasa tidak nyaman. Karena perasaan tidak nyaman tersebut membuat FN memutuskan untuk berkerudung hingga menutup bagian dada. LL secara lebih lanjut menjelaskan bahwa perasaan nyaman tersebut timbul karena ada perasaan kedamaian. LL membandingkan dengan perasaannya sebelum hijrah, yaitu ketika masih berpacaran ia merasa lebih gelisah serta takut yang akhirnya membuat LL merasa tidak nyaman. Perasaan nyaman juga timbul pada MI. MI merasa sangat nyaman ketika pertama kali mencoba cadar. Perasaan nyaman merujuk pada perasaan yang lebih bebas ketika melakukan sesuatu karena terbebas dari perhatian maupun pandangan orang lain. Lebih lanjut lagi, perasaan terbebas yang disampaikan oleh MI berkaitan dengan laki-laki, yaitu MI merasa tidak diganggu oleh laki-laki ketika menggunakan cadar. Hasil penelitian yang dilakukan oleh Cahyaningrum dan Desiningrum (2017) menunjukkan bahwa perasaan positif saat melihat wanita bercadar atau mengetahui tentang cadar yaitu kenyamanan mempelajari agama dengan kelompok wanita bercadar.

Perilaku yang ingin ditunjukkan oleh LL yaitu dengan memberikan sebuah pembuktian, pembuktian tersebut ditunjukkan dengan akhlak yang baik. Seperti halnya identitas sosial menurut Giddens dalam Barker (2004) yang diasosiasikan dengan hak-hak normatif, kewajiban dan sanksi yang pada kolektivitas tertentu membentuk sebuah peran. LL menunjukkan perannya sebagai muslimah bercadar dengan hak-hak normatifnya untuk melakukan dakwahnya, namun juga berkewajiban untuk tidak hanya berdakwah melalui mulut saja, namun juga melalui akhlak yang baik. LL melakukan dakwah dengan menunjukkan perilaku dan akhlak yang lebih baik. Tidak hanya melakukan hijrah dari pacaran namun hal tersebut juga bertujuan untuk membuktikan bahwa dengan bercadar LL mempelajari cara bersikap yang lebih baik, khususnya dengan menjadi anak yang lebih baik serta berbakti kepada orang tua. Hal tersebut didukung oleh penelitian yang dilakukan oleh Anindyajati (2013) bahwa sampel dengan status identitas tercapai, sedikit yang melakukan tingkat kenakalan menengah hingga berat. FN merasa bahwa kemampuan nya terbatas dalam membuat desain grafis untuk dakwah, namun keterbatasannya tidak membatasi dirinya untuk melakukkan dakwah. FN memiliki teman yang dirasa cukup mampu membuat desain latar belakang untuk kutipan dakwah, hal tersebut dianggap sebagai jalan dari Allah. FN menganggap bahwa dakwah merupakan perbuatan yang baik, sehingga ia tidak ragu untuk mengajak temannya tersebut untuk melakukan dakwah. Keredahan hati juga menjadi salah satu perilaku yang berusaha ditunjukkan. MI berusaha untuk tetap rendah hati dengan cara menyembunyikan amal ibadah yang telah dilakukannya. MI berusaha untuk selalu menata niatnya agar tidak menjadi pamer, salah satunya dengan cara tidak menunjukkan atau menyembunyikan amal ibadahnya. MI menjelaskan bahwa ia memiliki kekhawatiran memiliki niat yang kurang tepat ketika menunjukkan amal ibadah yang dilakukan. FN dan MI juga memiliki hak-hak normatifnya untuk melakukan dakwah baik secara langsung maupun melalui media sosial. Nasrullah (2011) menemukan hasil penelitian bahwa pengungkapan identitas muslim di dunia virtual atau internet memainkan peranan penting terhadap identitas diri.

Ketiga narasumber juga mengikuti sebuah komnitas yang sama, dimana komunitas tersebut dianggap sebagai sebuah tim dakwah. Hasil penelitian yang dilakukan oleh Syafiq (2012) menunjukkan bahwa motivasi untuk mengajak sebanyak mungkin mahasiswa lain untuk bergabung dalam 
komunitas minoritas membuat para aktivis dakwah berada dalam ketegangan antara tetap menjaga identitas "eksklusif" dengan tuntutan untuk bergaul luas secara inklusif agar pesan dakwah bisa diterima. Berdasarkan keterangan dari FN, ia mendapatkan banyak ilmu terkait cara berpakaian yang benar, akidah dan akhlak. Ilmu yang didapatkan dari komunitas dirasa cukup meyakinkan untuk dipercaya oleh FN. Lebih lanjut LL menyatakan bahwa di dalam komunitas tersebut terdapat bimbingan. Bimbingan diberikan kepada anggota komunitas yang nantinya akan menjadi panitia yang mengurus berjalannya sebuah kajian. MI menyebut bimbingan dengan nama halaqoh. Ia menambahkan bahwa dalam halaqoh tersebut terdapat pembina, pembina dalam halaqoh adalah seorang tokoh ulama atau ustadz. MI menganggap bahwa sebagai anggota komunitas yang akan mengurus berjalannya sebuah kajian, maka harus memahami materi yang akan disampaikan dalam kajian. Adanya halaqoh bertujuan untuk memberikan ilmu yang akan disampaikan pada kajian, sehingga ketika mengurus kajian, sehingga pengurus kajian tetap akan mendapatkan ilmu yang sama di kajian. Baik FN, LL maupun MI melakukan dakwah dalam lingkungan mayoritas tidak bercadar, sehingga membuat identitas mereka menjadi seolah "eksklusif" karena jumlahnya yang terbatas dan memperkuat ketergantungannya pada ingroup yaitu komunitas, ketergatungan dapat berbentuk perasaan adanya tempat untuk "kembali pulang" ketika dunia tidak dapat menerima identitasnya. Hal tersebut diperkuat dengan hasil penelitian yang dilakukan oleh Salim, Tonny, \& Wahyuningsih (2009) pada kaum minoritas yaitu etnis Tionghoa dengan hasil penelitian yang menyebutkan bahwa persepsi pribumi merupakan hasil warisan yang terpoles pengalaman buruk sehingga mengkonstruksi Identitas Tionghoa sebagai pendatang yang tidak berdaya dan pasif, sehingga jalan menyesuaikan diri dan bertahan dengan keadaan dan akhirnya memperkuat ketergantungan pada ingroup.

Bryant, et.al (Santrock, 2007: 197) menyebutkan salah satu faktor yang mempengaruhi pembentukan identitas adalah identitas budaya atau etnis, identitas individu yang berasal dari kelompok minoritas dalam proses pembentukan identitas memiliki dua dimensi yaitu kelompok etnisitas (minoritas) dan budaya yang dominan, dimana identitas etnis dianggap lebih kuat. Hal tersebut juga dirasakan oleh muslimah bercadar, dimana komunitas dakwah $\mathrm{P} * * * * * *$ berisi kaum minoritas yaitu muslimah bercadar serta pemakain pakaian syar'i. Penelitian yang dilakukan oleh Sartana dan Helmi (2014) ditemukan bahwa subjek memulai menyesuaikan diri dengan mengenali teman serta mengaktivasi diri yang sesuai.

Berdasarkan keterangan yang disampaikan oleh ketiga narasumber, dalam komunitas terdapat bimbingan yang biasa disebut dengan istilah halaqoh atau kajian internal yang rutin dilakukan seminggu sekali. Melalui bimbingan tersebut, terdapat interaksi antara anggota dengan anggota hingga interaksi antara anggota dengan pembina yang memperkuat hubungan di dalam komunitas tersebut. Lukito, Lidiawati, \& Matahari (2018) dalam penelitiannya menemukan bahwa di dalam komunitas, individu mendapatkan dukungan serta pengalaman dari anggota kelompok lain yang dianggap memiliki kedekatan khusus, sehingga pengaruh yang diberikan dapat lebih kuat. Bimbingan dalam komunitas tersebut dibina oleh seorang ustadzah yang juga bercadar. Komunitas tersebut mengidentifikasi dirinya sebagai tim dakwah yang menjaga cara berpakaian dengan taat sesuai syariat Islam. Sebagai tim dakwah, setiap anggota komunitas mendapatkan amanah untuk melakukan dakwah dalam hidupnya. Ketiga narasumber merasa senang ketika mendapatkan kepercayaan untuk melaksanakan amanah tersebut. Ancok (2002) 
menyatakan bahwa perasaan dipercaya akan membuat orang melihat bahwa orang lain peduli terhadap dirinya dengan menganggap orang lain adalah bagian dari dirinnya, dalam hal ini orang lain berkaitan dengan tokoh yang memberikan kepercayaan tersebut yaitu ustadzah dalam komunitas yang diikuti. FN mengaku bahwa ia mengagumi ustadzah yang biasa menjadi pembina saat dilakukan bimbingan. Hal tersebut sesuai dengan hasil penelitian yang dilakukan oleh Muniati, Erlan, \& Dahesihsari (2011) yaitu mereka memiliki identifikasi diri tinggi secara signifikan mengembangkan rasa percaya yang lebih tinggi pada figur dari kelompoknya.

Figur yang ada di dalam komunitas tersebut adalah ustadzah yang menggunakan cadar. Selain ustadzah, beberapa anggota komunitas juga sudah menggunakan cadar dan mayoritas anggota komunitas telah menggunakan pakaian yang dianggap sudah menutup aurat dengan benar, yaitu pakaian yang longgar dan tidak memperlihatkan bentuk tubuh serta tidak transparan. O'Sears, Freedman, \& Peplau (1985) menyatakan bahwa perilaku yang ditunjukkan oleh seseorang yang disebabkan karena orang lain juga menampilkan perilaku tersebut disebut dengan konformitas. FN awalnya menyatakan bahwa ia malu ketika pertama masuk ke komunitas tersebut, hingga menjadi lebih percaya diri ketika menggunakan cadar dan pakaian syar'i yang juga dilakukan oleh anggota komunitas tersebut. FN dan LL menggunakan cadar setelah masuk ke dalam komunitas tersebut.

Seperti halnya komunitas sebagai identitas etnis yang menjadi salah satu faktor dalam mempengaruhi pembentukan identitas dari muslimah bercadar, lingkungan umum sebagai identitas budaya (mayoritas atau budaya yang dominan) juga menjadi salah satu faktor yang disebutkan oleh Bryant, et.al. (Santrock, 2007). Lingkungan pertemanan ketiga narasumber bukanlah lingkungan mayoritas berpakaian syar'i. Tempat ketiga narasumber kuliah juga merupakan yayasan yang didirikan oleh Yayasan non-Islam, namun teman-teman narasumber cenderung cuek (tidak mendukung dan tidak menghambat) terhadap identitas narasumber sebagai muslimah bercadar. Lingkungan tetangga ketiga narasumber masih banyak yang belum berpakaian sesuai dengan syariat Islam menurut mereka. Bahkan ada beberapa tetangga yang menuduh LL sebagai bagian dari salah satu aliran yang dianggap radikal, namun hal tersebut direspon dengan cuek oleh LL. Tuduhan sebagai teroris juga ditemui oleh FN dan MI ketika sedang berada di keramaian. Hal tersebut membuat ketiga narasumber mengidentifikasi dirinya sebagai orang yang cuek dan tidak mempedulikan pendapat orang yang dianggap tidak penting. Takwin (2008) juga menemukan dalam penelitiannya bahwa diri seseorang terbentuk dan berkembang dalam interaksinya dengan orang lain dalam kehidupan sosial.

Identitas baru sebagai seorang muslimah bercadar merupakan hal yang sangat berbeda dengan identitas sebelumnya sebagai muslimah yang tidak bercadar. Pembetukan identitas atau rekonstruksi identitas pada narasumber melibatkan ketiga aspek penting dalam dinamika psikologi yaitu kognitif, perasaan dan perilaku. Pengalaman masa lalu yang dialami oleh narasumber berkaitan dengan lelaki yang tidak baik menjadi salah satu alasan untuk membatasi hubungannya dengan laki-laki dengan belajar lebih mendalam terkait aturan berhubungan dengan laki-laki yang merujuk pada ketaatan terhadap hukum agama yang semakin kuat. Perubahan pola kognitif terkait hubungan dengan laki-laki yang semakin jelas mengenalkan narasumber dengan cadar hingga sangat meyakini bahwa cadar sangat bermanfaat. Pola kognitif lain yang diperkuat yaitu terkait keteladan terhadap kepribadian Rasul, dalam menjalani kehidupan dan menyelesaikan masalah, muslimah bercadar selalu menjadikan Rasul, sahabat Rasul dan 
Istri Rasul sebagai contoh dan rujukan untuk kehidupan yang lebih baik. Aspek kognitif tersebut diperkuat dengan adanya aspek afektif atau perasaan, yaitu perasaan nyaman yang timbul dalam diri ketiga narasumber, sehingga membentuk perilaku yaitu dengan menunjukkan perilaku yang baik menurut versi mereka. Perilaku tersebut ditunjukkan dengan akhlak yang lebih baik dan berbakti kepada orang orang, yang dilanjutkan dengan mengajak orang lain untuk berperilaku yang juga baik. Selain ketiga aspek tersebut, terdapat tiga faktor yang mempengaruhi rekonstruksi identitas pada muslimah bercadar, yaitu keluarga, komunitas, dan lingkungan umum.

Pada penelitian ini, peneliti telah berusaha semaksimal mungkin untuk memberikan hasil yang terbaik, namun karena ada keterbatasan dari segi waktu, tenaga, maupun kesempatan maka hasil yang dicapai dalam penelitian ini masih perlu banyak diperbaiki. Keterbatasan penelitian tersebut antara lain adalah sebagai berikut : 1) Sejauh yang sudah dilakukan, peneliti telah berusaha untuk membuat narasumber nyaman, namun karena peneliti tidak berasal dari komunitas yang sama maka peneliti merasa ada hal-hal yang tidak disampaikan narasumber seperti yang diharapkan, 2) Terjadi kerusakan rekaman wawancara kedua pada narasumber pertama, sehingga narasumber harus mengulang kembali wawancara kedua pada narasumber pertama,3) Wawancara kedua yang dilakukan pada narasumber kedua berlangsung dengan sedikit terburu-buru dengan durasi wawancara kurang lebih 45 menit, hal tersebut karena narasumber kedua harus mempersiapkan kajian yang akan dilaksanakan saat itu.

\section{SIMPULAN}

Berdasarkan hasil analisis yang ditemukan pada ketiga narasumber yaitu berkaitan dengan fungsi kognitif, perasaan, perilaku dan faktor yang mempengaruhi sebagai unsur-unsur yang membangun dinamika psikologi yang lengkap yang dirumuskan berdasarkan tema-tema superordinat yang muncul. Fungsi kognitif yang muncul pada muslimah bercadar yaitu pemikiran bahwa cadar sangat bermanfaat, ketaatan terhadap hukum agama semakin kuat, keinginan berbuat baik agar mendapatkan surga, pengalaman buruk dengan laki-laki hingga mengenal cadar, serta meneladani kepribadian Rasul dan sahabat Rasul. Tema terkait perasaan yaitu perasaan lebih nyaman ketika bercadar. Tema terkait perilaku yaitu berperilaku sebaik mungkin dan mengajak orang lain. Tema terkait faktor dari luar atau faktor eksternal yang mempengaruhi muslimah bercadar yaitu keluarga yang memahami keputusan untuk bercadar, pengaruh komunitas dakwah $\mathrm{P}^{* * * * * * *}$ yang cukup kuat, serta lingkungan pertemanan, tetangga dan masyarakat umum yang kurang mendukung. Tema-tema tersebut selanjutnya disimpulkan mengarah pada rekonstruksi identitas pada muslimah yang bercadar.

Saran bagi peneliti selanjutnya yang akan melakukan melakukan penelitian terkait muslimah bercadar untuk memperhatikan unit analisis lain yang diprediksi terkait dengan jumlah muslimah bercadar yang semakin bertambah Peneliti selanjutnya dapat memperhatikan penggunaan cadar terkait narasumber yang menggunakan niqab (cadar dengan tambahan penutup bagian kening) atau burqo (cadar yang menutup seluruh wajah, dan menggunakan kain transparan untuk melihat namun tetap menutup bagian mata).

\section{DAFTAR PUSTAKA}

Amanda, R., \& Mardianto. (2014). Hubungan Antara Prasangka Masyarakat Terhadap Muslimah Bercadar dengan Jarak Sosial. Jurnal RAP UNP, 7281. 
Ancok, D. (2002). Membangun Kepercayaan Menuju Indonesia Madani, Demokratis dan Damai (Sebuah Tinjauan Psikologi Sosial). Buletin Psikologi, 45-57.

Anindyajati, P. D. (2013). Status Identitas Remaja Akhir : Hubungannya dengan gaya pengasuhan orang tua dan tingkat kenakalan remaja. Character, 1-6.

Barker, C. (2004). Cultural Studies, Teoeri \& Praktik. Yogyakarta: Kreasi Wacana.

Baron, R. A., \& Byrne, D. (2003). Psikologi Sosial Edisi Kesepuluh Jilid 1. Jakarta: Erlangga.

Berry, A. (2018, Maret 6). Larangan memakai cadar di UIN: Antara kebebasan memilih dan ancaman radikalisme. $B B C$ Indonesia. Retrieved from https://www.bbc.com/ indonesia/trensosial-43298214

Cahyaningrum, D. R., \& Desiningrum, D. R. (2017). Jiwa-Jiwa Tenang Bertabir Iman : Studi Fenomenologi pada Mahasiswa Bercadar di Universitas Negeri Umum Kota Yogyakarta. Jurnal Empati, 278-296.

Deliana, S. M., \& Sunuhadi, B. (2013). Status Identitas Remaja dengan Latar Belakang Keluarga Etnis Jawa dan Tionghoa. Intuisi, 35-38.

Desiningrum, D. R. (2010). Family's Social Support and Psychological Well Being of the Elderly in Tembalang. Anima, 61-68.

Falatehan, S. F. (2017). Community Psychology Aprroach in Predicting The Role of Sense of Community in Eliciting Community Participation. Jurnal Ilmiah Psikologi MANASA, 66-90.

Feinberg, R. A., Mataro, L., \& Burroughs, W. J. (2015). Clothing and Social
Identity. Clothing and Textilles Research Journal, 18-23.

Kahija, Y. L. (2007). Penelitian Fenomenologis. Yogyakarta: PT Kanisius.

Lukito, A. C., Lidiawati, K. R., \& Matahari, D. (2018). Sense of Community dan Self-Efficacy Pada Mahasiswa Yang Mengikuti Komunitas Kesenian. Jurnal Psikologi Talenta, 9-20.

M.Kang, J.Y., Johnson, K. K., \& Kim, J. (2013). Clothing Functions and use of Clothing to Alter Mood. International Journal of Fashion Design, Technology and Education, 43-52.

Muniati, J., Erlan, H. W., \& Dahesihsari, R. (2011). Self-Identification and Trust Towards Ingroups. Anima, 91-103.

Muttaqin, D., \& Ekowarni, E. (2016). Pembentukan Identitas Remaja di Yogyakarta. Jurnal Psikologi, 231247.

Nasrullah, R. (2011). Konstruksi Identitas Muslim di Media Baru. Komunika, 221-234.

Nisa, Khairun., \& Rudianto. (2017). Trend Fashion Hijab Terhadap Konsep Hijabers Komunitas Hijab Medan. Jurnal Interaksi, 105-117

Nurhayat, M. A. (2018). Mahasiswi Hijabers (Studi Living Qur'an tentang Pemahaman Jilbab Menurut Mahasiswi IQT). JIA, 106-123.

Nusawakan, A. W., Ranimpi, Y. Y., \& kawonal, J. R. (2012). The Spiritual Aspect In Post-Amputations Client. Anima, 41-46.

O'Sears, D., Freedman, J. L., \& Peplau, L. A. (1985). Psikologi Sosial Edisi Ke Lima Jilid 2. Jakarta: Erlangga. 
Putra, A. K. (2011). Family Social Support and Work Stress on Night Shif Bus Drivers. Anima, 248-258.

Putra, I. E., \& Maria, L. (2008). Konstruksi Sosial dan Pendekatannya dalam Psikologi. JPS, 263-273.

Rahmawati, I. (2017). Nilai Sense of Community pada Kesejahteraan Psikologis dalam Menghuni (Housing Well-Being): Studi Meta-analisis. Psikohumaniora: Jurnal Penelitian Psikologi, 81-93.

Rasyid, L. A. (2018). Problematika Hukum Cadar dalam Islam : Sebuah Tinjauan Normatif-Historis. Jurnal Ilmiah AlSyir'ah, 74-92.

Rinawati, R (2007). "Lifestyle" Muslimah. Mediator, 65-76.

Salim, C., Tonny, \& Wahyuningsih, S. (2009). Kristalisasi Persepsi Terhadap Pribumi Pada Perempuan Tradisonal Tionghoa : Sebuah Life History. Anima, 142-159.

Santrock, J. W. (2007). Remaja Edisi Sebelas Jilid 1. Jakarta: Erlangga.

Sartana, \& Helmi, A. F. (2014). Konsep Diri Remaja Jawa Saat Bersama Teman. Jurnal Psikologi, 190-204.

Soeparno, K., \& Andayani, B. (2014). Social and Climate Change: Impact on Human Behavior. Anima, Indonesian Psychological Journal, 1-7.

Sugiyono. (2001). Metode Penelitian Administrasi. Bandung: Penerbit Alfabeta.
Sugiyono. (2013). Metode Penelitian Pendidikan Pendekatan Kuantitaif Kualitatif dan $R \& D$. Bandung: Alfabeta.

Sugiyono. (2014). Memahami Penelitian Kualitatif. Bandung: Penerbit Alfabeta.

Syafiq, M. (2012). Berbaur Tapi Tidak Lebur: Membentuk dan Mempertahankan Identitas Religius Pada Mahasiswa Aktivis Dakwah Kampus. Jurnal Psikologi : Teori dan Terapan, 1-16.

Taklimudin, \& Saputra, F. (2018). Metode Keteladanan Pendidikan Islam dalam Perspektif Qur'an. Jurnal Pendidikan Islam, 1-22.

Takwin, B. (2008). Diri dan Pengelolaannya. JPS, 181-192.

Tanra, I. (2016). Persepsi Masyarakat Tentang Perempuan Bercadar. Jurnal Equilibrium, 117-126.

Utami, M. S. (2012). Religiusitas, Koping Religius dan Kesejahteraan Subjektif. Jurnal Psikologi, 46-66.

Yanggo, H. T. (2010). Fikih Perempuan Kontemporer. Bogor: Ghalia Indonesia.

Yazid, T. P., \& Ridwan. (2017). Proses Persepsi Diri Mahasiswi dalam Berbusana Muslimah. Jurnal Annida', 193-201.

Yusuf, S. (2004). Psikologi Perkembangan Anak dan Remaja. Bandung: PT. Remaja Rosdakarya. 